\title{
Determining the Impact of Subjective Well-Being on Academic Achievement of Children in District Faisalabad
}

\author{
Adeela Manzoor \\ Institute of Rural Home Economics, University of Agriculture, Faisalabad, Pakistan \\ adeela.manzoor@yahoo.com \\ Dr. Aisha Siddique \\ Institute of Rural Home Economics, University of Agriculture, Faisalabad, Pakistan \\ Corresponding author Email: aisha_riz@yahoo.com \\ Dr. Farah Riaz \\ Institute of Rural Home Economics, University of Agriculture, Faisalabad, Pakistan \\ farah_riaz_uaf@yahoo.com \\ Dr. Ayesha Riaz \\ Institute of Rural Home Economics, University of Agriculture, Faisalabad, Pakistan \\ i_sha_r@yahoo.com
}

\author{
Doi:10.5901/mjss.2014.v5n23p2673
}

Abstract

Subjective well-being (SWB) is the form of well-being which focuses on people's feelings, life satisfaction, happiness and their emotions. Subjective well-being also influences the academic achievement of children. The present study is designed to investigate the subjective well-being level in Pakistani children. Furthermore, to investigate the gender difference with relation to SWB and to determine the impact of subjective well-being on academic achievement of children. $A$ validated and reliable Personal Well-being Index- School Children Scale (PWI-SC) was used. By simple random sampling 200 Students (9-12 years) were taken from the private and public schools. The collected data was analysed by bivariate correlation and independent $t$ test. Results show that most of the children (61.5\%) have higher level of subjective well-being. Gender difference $(p=0.001)$ was found as boys have higher level of SWB than girls. Results demonstrate a significant positive relationship $(p=0.035, r=$ 0.149) between subjective well-being and academic achievement. It is concluded that the level of SWB in Pakistani children is high and gender difference exist with relation to SWB. Subjective Well-being and academic achievement are positively associated with each other. The society in general and parents in particular should avoid the gender difference for their affection. Workshops and trainings must be organized for parents and teachers to realize them that their behaviors and attitude has great effect on student SWB and academic achievement.

Keywords: Subjective Well-being; Life Satisfaction; Personal Well-Being Index Scale (PWI-SC); Positive Effect; Negative Effect; Academic Achievement; Faisalabad

\section{Introduction}

A good life comes about when an individual has experiences and makes choices that bring about enjoyment and allow the individual to use signature strengths, achieving abundant and genuine fulfilment.The term "well-being" is used for the people's quality of life.Well-being is composed of intellectual assessment and emotional responses in various situations of individual's life (Campbell et al. 1976). Well-being is a state of successful performance throughout the life course which includes strength in physical, cognitive, and social-emotional functioning as well as the successful integration of these three domain functions (Bornstein et al. 2003). The two concepts of wellbeing are usually referred to as hedonic and eudaimonic (Ryan \& Deci, 2001; Ryff et al. 2004). Hedonic wellbeing refers to feeling good, whereas eudaimonic wellbeing refers to living a good life i.e. meaningful, honourable, or realistic (Henderson \& Knight, 2012). A measure of hedonic wellbeing is often called subjective wellbeing (SWB). 
SWB is generally defined as the optimistic situation of mind that encompasses all over the life for different practices in daily routine (Blore et al. 2010). "A positive psychological state characterized by a high level of satisfaction with life, a high level of positive affect and a low level of negative affect" (Carr 2004). SWB is a multidimensional assessment of life which is used to assess the feelings and tempers of people as well as intellectual judgments of life agreement (McGillivray and Clarke, 2006). Subjective well-being has three primary components: life satisfaction, positive affect (happiness, High hope etc) and negative affect (Diener, 1984).

Life satisfaction is referred to an intellectual assessment of overall individual's quality of life generally and specifically in different areas such as satisfaction with marriage, work and school (Myers and Diener, 1995; Zullig et al. 2005). Positive affectivity is a characteristic which is based on the individual differences how they express their positive emotional experiences in different situations such as passion, gratification, satisfaction and these situations reflect the individual's positive emotions such as joy happiness, high hope, confidence, enthusiasm and awareness (Carr, 2004; Snyvder and Lopez, 2002). Negative affect is the level of expression of negative emotions in which individual easily suffer from bad tempered, prone to anger and disappointment. It is specific state of distress and displeasure that is composed by negative emotions such as fear, sadness, blame, dislike and disgust (Kail and Cavanaugh, 2007). These two cognitive and emotional aspects form the core of subjective well-being and these aspects are fully intertwined. Cognitive component refers to life satisfaction and the emotional component divided into positive and negative effect (Bradburn, 1969; Diener, 1998). The emphasis in this study falls on the cognitive component i.e. Life satisfaction.

Gender differences in the normal range of SWB show a somewhat different picture. Past researches represent varied results about gender difference. Most of the studies show that females report low level of subjective well-being than males (Smith and Reise, 1998; Baltes et al. 1999). Some studies show higher positive affect and life satisfaction in women (Fujita et al. 1991; Haller and Hadler 2006), where as Okum and George, (1984) reported that there is no gender difference in SWB.

Higher subjective well-being (quality of life satisfaction, positive and negative effect) and higher academic achievement has crucial link with each other. Children with high life satisfaction are more intelligent and get high grades in their studies rather than those children who had more negative thinking and low life satisfaction they report lower grades in academic performance (Gilman and Huebner, 2006). High hope expected successful school related outcomes. Higher global academic performance, as well as elevated expectancies of success, was also found in students with high hope (Curry et al. 1997).

\subsection{Statement of the problem}

In Pakistani society people are unable to understand the notion of subjective well-being and its importance in academic achievement. No data is available about the level of SWB of children and its impact on academic achievement. Keeping this in mind the present study was formulated to determine the level of subjective well-being in Pakistani children. Furthermore, to investigate the gender difference with relation to SWB and to determine the impact of subjective wellbeing on academic achievement of children.

\subsection{Hypothesis}

1. There will be a significant difference in subjective well-being of children on the basis of gender.

2. There will be a significant relationship between subjective well-being and academic achievement of children.

\section{Methodology}

\subsection{Design}

The study used a descriptive survey and ex-post research design. As independent variable SWB, which is investigated, has already occurred and researcher only investigated its influence on criterion variable (student academic achievement) without manipulating the independent variable.

\subsection{Population and Sample}

The present study was conducted in Faisalabad city. By using simple random sampling technique, a sample of 200 respondents (100 male and 100 female) from both public and private schools were selected. 


\subsection{Instruments}

In order to determine the SWB of children a validated questionnaire Adapted Personal Well-Being Index (PWI-SC) was employed. This scale was developed by Cummins et al. (2003). Basically, this questionnaire has seven questions related to satisfaction about different areas of life but later on two other questions of satisfaction related to school and use of time were included as recommended by Tomyn et al. (2011) and cases et al. (2012) respectively. This scale has designed according to the end-labelled format. The style of this format is range from (0) completely dissatisfied to (10) completely satisfied at the number (5) is the neutral point that is not satisfied or dissatisfied. The advantage of this neutral point was to make clear range for children from positive to negative values. A demographic questionnaire was also employed.

Furthermore to assess the academic achievement the term-end report card grades of each student from school records were collected.

\subsection{Administration of the Instrument and Data Analysis}

The data was collected from the respondents through face to face interview schedule. The data was analyzed through SPSS (Statistical Package for Social Sciences) and meaningful, presentable Statistical technique such as frequency distribution and percentage analysis, bivariate correlation and independent $t$ test was employed.

\section{Results}

Table I: Demographic Variables

\begin{tabular}{|c|c|c|}
\hline Variables & & Frequency \\
\hline \multirow{3}{*}{ Gender } & Male & $\begin{array}{c}100 \\
(50 \%)^{\star}\end{array}$ \\
\hline & Female & $\begin{array}{c}100 \\
(50 \%)\end{array}$ \\
\hline & Total & $\begin{array}{c}200 \\
(100 \%)\end{array}$ \\
\hline \multirow{3}{*}{ Age (Years) } & $9-10$ & $\begin{array}{c}90 \\
(45 \%)\end{array}$ \\
\hline & $11-12$ & $\begin{array}{c}110 \\
(55 \%)\end{array}$ \\
\hline & Total & $\begin{array}{c}200 \\
(100 \%)\end{array}$ \\
\hline
\end{tabular}

The table I indicates that 50.0 percent of the respondents were the male and 50.0 percent of the respondents were female. Most of the respondents were $11-12$ years of age (55\%).

Table II: Student's Level of Subjective Well-Being

\begin{tabular}{|c|c|}
\hline Categories & Frequency \\
\hline Low & 15 \\
$(7.5 \%)$ \\
\hline Moderate & 62 \\
& $(31.0 \%)$ \\
\hline High & 123 \\
$(61.5 \%)$ \\
\hline Total & 200 \\
& $(100 \%)$ \\
\hline
\end{tabular}

(\% in parentheses) 
The table II indicates that very small numbers of children have low SWB (7.5\%) and most of the children have higher level of SWB (61.5\%).

Table III: Difference in Subjective Well-Being on the Basis of Gender

\begin{tabular}{|c|c|c|c|c|c|}
\hline Gender & N & Mean & Std. Deviation & T & $p$-value \\
\hline Boy & 100 & 74.8400 & 10.77288 & 1.530 & 0.001 \\
Girl & 100 & 72.1600 & 13.80874 & & \\
\hline
\end{tabular}

The table III shows that boys have significantly $(p=0.001)$ higher level of subjective well-being than girls. This implies that hypothesis, which stated that there will be a significance difference in SWB on the basis of gender was accepted. It means that SWB differs on the basis of gender.

Table IV: Relationship between Subjective Well-Being and Academic Achievement of Students.

\begin{tabular}{|l|c|c|c|c|}
\hline & N & SD & r & $p$-value \\
\hline Academic Achievement & 200 & 16.16 & $0.149^{*}$ & 0.035 \\
SWB & 200 & 12.42 & \\
\hline
\end{tabular}

${ }^{*}$ Correlation is significant at the 0.05 level (2-tailed)

The table IV shows a significant and positive bivariate correlation $(p=0.035$ and $r=0.149)$ between subjective well-being and academic achievement of children. This implies that hypothesis, which stated that there will be a significant relationship between SWB and academic achievement of children was accepted. It, therefore, means that SWB of students would influence student academic achievement.

\section{Discussion}

The aim of present study is to investigate the level of subjective well-being in Pakistani children. Furthermore, to investigate the gender difference with relation to SWB and to determine the impact of subjective well-being on academic achievement of children. Results revealed that the level of SWB in Pakistani children is high and gender difference exists with relation to SWB. Subjective Well-being and academic achievement are positively associated with each other.

With regard to determine the level of SWB the study shows that most of the children ( $9-12$ years of age) have higher level of subjective well-being. In Pakistan, strong family pattern and intimate relationship of parents with children is positive indicator for higher level of subjective well-being in children. Because those children, who have family attachment and living with both parents usually have higher level of SWB. These children have good communication skills for community dealings, have strong social relationships and have good dealings with school mates (Casas et al. 2009).

With regard to SWB and the gender difference the study found that boys have higher level of subjective well-being. This finding is consistent with the findings of Coleman and Hendry, (1990) and Diener \& Diener, (1995). Coleman and Hendry, (1990) observed that boys get more opportunities for developing social interactions, experiences emotions and express feelings for age mates of the same or opposite sex due to these dealings boys are more satisfied from life as compared to girls. Diener \& Diener, (1995) reported that social rejection and isolation may decrease SWB. Generally, in Pakistan girls face more social rejection than boys which may be ascribed to their low SWB. While, Natvig et al. (2003) found no significant differences between boys and girls with respect to their reported level of subjective well-being. However, the Present finding is in contradiction with the finding of Haller and Hadler (2006) who found that women scored significantly higher both on happiness and life satisfaction in every field of life. A possible explanation for this difference is may be that in Pakistan females mostly faced social rejection and ignorance in every field from the society but in developed countries policies aimed at improving gender equality and society gives respect, rights to security and freedom of individuality to the women as a result women feel satisfied and relaxed in their lives.

With respect to the SWB and its association with academic achievement of children. The study found that students who are more satisfied with their lives have higher level of academic performance. This finding is parallel with the finding of past researches which suggests that SWB is associated with academic achievement (Gilman and Huebner, 2006; Curry et al. 1997; Lyubomirsky et al. 2005). Children with high life satisfaction are more intelligent and get high grades in their studies compared to those children who had more negative thinking and low level of satisfaction and got lower grades in academic performance (Gilman and Huebner, 2006). Curry et al. (1997) reported that high hope and life 
satisfaction predicted successful school related outcomes. Higher global academic goals, as well as elevated expectancies of success, were also found in students with high hope. Lyubomirsky et al. (2005) observed that happiness and academic achievement are mutually reinforcing. Children higher in subjective well-being earn higher grades, even when controlling for intelligence and past academic performance.

\section{Conclusion}

The study fills the existing gap by providing the level of SWB of Pakistani children. For the first time the study clearly provides evidence that most of the children fall in higher level of subjective well-being. The study showed that there is a significant relationship between subjective well-being and academic achievement. Furthermore, the study found that gender has an effect on subjective well-being. The boys showed higher subjective well-being than girls.

\section{Suggestions}

Keeping in view the lower level of subjective well-being of girls the society in general and parents in particular should avoid the gender difference for their affection. They should develop the feeling of security and life satisfaction in girls in order to build higher subjective well-being in them. Highlighting the importance of impact of subjective well-being on academic achievement workshops and trainings must be organized for teacher's to realize them that their behaviors and attitude has great effect on student SWB and eventually on academic performance. Supportive parenting styles and high quality interactions of parents with girls must be introduced in family for the development of life satisfaction.

\section{References}

Baltes, M. M., Freund, A.M., \& Horgas, A.L. (1999). Men and women in the Berlin aging study. In P. B. Baltes, \& K. U. Mayer (Eds.), The Berlin aging study: Aging from 70 to 100 (pp. 259-281). Cambridge: Cambridge University Press.

Blore, J.D., Stokes, M. A., Mellor, D., Firth, L., \& Cummins, R.A. (2010). Comparing multiple discrepancies theory and affective models of subjective wellbeing. Social Indicators Research. Doi: 10.1007/s11205-010-9599-2.

Bornstein, M., Davidson, H., Keyes, L., \& Moore, K.A. (2003). Well-being: Positive development across the life course. New Jersey: Lawrence Erlbaum Associates, Mahwa.

Bradburn, N.M. (1969). The structure of psychological well-being, Chicago: Aldine.

Campbell, A., Converse, P.E., \& Rodgers, W.L. (1976). The quality of American life: Perceptions, evaluations, and satisfactions. New York: Russell Safe Foundation. Cantril, H. 1965. The pattern of human concerns. New Jersey: Rutgers University Press

Carr, A. (2004). Positive psychology: The Science of Happiness and Human Strengths. East Sussex: Routledge.

Casas, F., S. Bălțătescu, S., González, M., \& Hatos, A. (2009). Similarities and differences in the PWI of Romanian and Spanish adolescents aged 13-16 years-old. Conference presentation. International Society for Quality of Life Studies. Florence: Italy, July 19-23.

Casas, F., Coenders, G., González, M., Malo, S., Bertran, I., \& Figuer, C. (2012).Testing the relationship between parents and their own children subjective well-being Journal of Happiness Studies, 13, 1031 - 1051.

Coleman, J.C., \& Hendry, L. (1990). The Nature of Adolescence (2nd Ed). London: Routledge.

Cummins, R., Eckersley, R., Pallant, J., Van Vugt, J., \& Misajon, R. (2003). Developing a national index of subjective wellbeing: The Australian unity wellbeing index. Social Indicators Research, 64, 159-190.

Cummins, R. A., \& Lau, A. (2005). Manual: personal wellbeing index - school children. Third edition. Resource document. Melbourne: Deakin University Press.

Curry, L.A., Snyder, C.R., Cook, D.L., Ruby, B.C., \& Rehm, M. (1997). Role of hope in academic and sport achievement. Journal of Personality and Social Psychology, 73, 1257-1267.

Diener, E. (1984). Subjective well-being. Psychological Bulletin, 95, 542-575.

Diener, E. (1998). Subjective well-being and personality. In D.F. Barone., M. Hersen., \& V.B, an Hassett (Eds.), Advanced Personality (pp. 311-334). New York: Plenum.

Diener, E., \& Diener, C. (1995).Factors predicting the subjective well-being of Nations. Journal of Personality and Social Psychology, 5 , 851-864.

Fujita, F., Diener, E., \& Sandvik, E. (1991).Gender differences in negative affect and well-being: The case for emotional intensity'. Journal of Personality and Social Psychology, 61, 427-434.

Gilman, R., \& Huebner, E.S. (2006). Characteristics of adolescents who report very high life satisfaction. Journal of Youth and Adolescence, 35, 311-319.

Haller, M., \& Hadler, M. (2006). How social relations and structures can produce happiness and unhappiness: An international comparative analysis. Social Indicators Research, 75, 169-216.

Henderson, L. W., \& Knight, T. (2012). Integrating the hedonic and eudaimonic perspectives to more comprehensively understand wellbeing and pathways to wellbeing. International Journal of Wellbeing, 2, 196-221. 
Kail, R.V., \& Cavanaugh, J.C. (2007). Human Development: A life-span view. Canada: Thomson Wadsworth.

Lyubomirsky, S., King, L., \& Diener, E. (2005). The benefits of frequent positive affect: Does happiness lead to success? Psychological Bulletin, 131, 803-855.

McGillivray, M., \& Clarke, M. (2006). Human Well-being: Concepts and Measures. In Mark McGillivray and Matthew Clarke (Eds), Understanding Human Well-Being. (pp. 3-16), Basingstoke: United Nations University Press.

Myers, D., \& Diener, E. (1995). Who is happy? Psychological Science, 6, 10- 19.

Natvig, G.K., Albreksten, G., \& Qvarnstrom, U. (2003). Associations between psychosocial factors and happiness among school adolescents. International Journal of Nursing Practice, 9, 166-175.

Okun, M. A., \& George, L.K. (1984). Physician- and self-ratings of health, neuroticism, and subjective well-being among men and women. Personality and Individual Differences, 5, 533-539.

Ryan, R. M., \& Deci, E.L. (2001). On happiness and human potentials: A review of research on hedonic and eudaimonic well-being. Annual Review of Psychology. 52, 141-166.

Ryff, C. D., Singer, B.H., \& Love, G.D. (2004). Positive health: Connecting well-being with biology. Philosophical Transactions of the Royal Society, 359, 1383-1394.

Snyder, C.R., \& Lopez, S.J. (2002). Handbook of Positive Psychology. London: Oxford University Press.

Smith, L. L., \& Reise, S. P. (1998). Gender differences on negative affectivity: An IRT study of differential item functioning on the multidimensional personality questionnaire stress reaction scale. Journal of Personality and Social Psychology, 75, $1350-1362$.

Tomyn, A. J., Tyszkiewicz, M.F., \& Cummins, R.A. (2011). The Personal Wellbeing Index: Psychometric Equivalence for Adults and School Children. Social Indicators Research. Doi: 10.1007/s11205-011-9964-9.

Zullig, K.J., Huebner, E.S., Gilman, R., Patton, J.M., \& Murray, K.A. (2005). Validation of the Brief Multidimensional Students' Life Satisfaction Scale among college students. American Journal of Health Behavior, 29, 206-214. 